\title{
Effect on Cessation Counseling of Document- ing Smoking Status as a Routine Vital Sign: An ACORN Study
}

Stephen F. Rothemich, MD, MS

Steven H. Woolf, MD, MPH

Robert E. Jobnson, $P b D^{2}$

Amy E. Burgett, RN ${ }^{3}$

Sharon K. Flores, MS

David W. Marsland, $M D^{3}$

Jasjit S. Abluwalia, MD, MPH, MS ${ }^{4}$

'Departments of Family Medicine and Epidemiology and Community Health, Virginia Commonwealth University, Richmond

${ }^{2}$ Departments of Biostatistics and Family Medicine, Virginia Commonwealth University, Richmond

${ }^{3}$ Department of Family Medicine, Virginia Commonwealth University, Richmond

${ }^{4}$ Office of Clinical Research, University of Minnesota, Minneapolis

\begin{abstract}
PURPOSE Guidelines encourage primary care clinicians to document smoking status when obtaining patients' blood pressure, temperature, and pulse rate (vital signs), but whether this practice promotes cessation counseling is unclear. We examined whether the vital sign intervention influences patient-reported frequency and intensity of tobacco cessation counseling.
\end{abstract}

METHODS This study was a cluster-randomized, controlled trial conducted in the Virginia Ambulatory Care Outcomes Research Network (ACORN). At intervention practices, nurses and medical assistants were instructed to assess the tobacco use status of every adult patient and record it with the traditional vital signs. Control practices did not use any systematic tobacco screening or identification system. Outcomes were the proportion of smokers reporting clinician counseling of any kind and the frequency of 2 counseling subcomponents: simple quit advice and more intensive discussion.

RESULTS A total of 6,729 adult patients $(1,149$ smokers $)$ at 18 primary care practices completed exit questionnaires during a 6 -month comparison period. Among 561 smokers at intervention practices, $61.9 \%$ reported receiving any counseling, compared with $53.4 \%$ of the 588 smokers at control practices, for a difference of $8.6 \%(P=.04)$. The effect was largely restricted to simple advice, which was reported by $59.9 \%$ of intervention patients and $51.5 \%$ of control patients $(P=.04)$. There was no significant increase in more extensive discussion, with $32.5 \%$ and $29.3 \%$ of patients at intervention and control practices, respectively, reporting this type of counseling $(P=.18)$.

CONCLUSIONS The vital sign intervention promotes tobacco counseling at primary care practices through a modest increase in simple advice to quit. When implemented as a stand-alone intervention, it does not appear to increase intensive counseling.

Ann Fam Med 2008;6:60-68. DOI: 10.1370/afm.750.

\section{INTRODUCTION}

巨 ew interventions are more important to public health than promoting cessation of tobacco use. ${ }^{1}$ Tobacco use is the leading cause of death in the United States, claiming an estimated 440,000 lives per year., ${ }^{2,3}$ Health professionals play a key role in promoting tobacco cessation: smokers cite physician advice as a major determinant in quitting ${ }^{4,5}$ and even simple advice from physicians has been shown to significantly increase abstinence rates. ${ }^{6}$ If clinicians helped as few as $10 \%$ of smokers to quit, 3.5 million smokers would become tobacco free each year. ${ }^{7}$

In 1996, the US Department of Health and Human Services (DHHS) issued formal guidelines urging primary care clinicians to adopt officewide systems, such as the vital sign intervention, to assess smoking status systematically. ${ }^{8}$ This recommendation was reiterated and updated in $2000,{ }^{9}$ 
and it was incorporated by the National Committee for Quality Assurance into its Health Plan Employer Data and Information Set (HEDIS). A survey in 2000 showed that $43 \%$ of health plans required clinicians to record smoking status as part of patients' vital signs (blood pressure, temperature, and pulse rate). ${ }^{10}$

Scientific evidence to support this recommendation was limited. The DHHS guideline based its recommendation on 3 studies ${ }^{11-13}$ reporting increased counseling at practices that adopted the vital sign intervention, but these studies relied on before-and-after designs, were subject to confounding and limited generalizability, or both. Studies published after the release of the DHHS guidelines found that the vital sign intervention did not increase subsequent counseling. ${ }^{14-17}$

Well-designed studies are needed both to confirm whether the vital sign intervention increases counseling and to clarify the intensity of any resultant counseling as defined by the "5As" framework (Table 1). Because simple advice to quit $\left(\mathrm{A}_{2}\right)$ is less effective in promoting abstinence than more intensive counseling $\left(\mathrm{A}_{3-5}\right)_{1}{ }^{18-21}$ knowing whether the vital sign intervention increases not only $\mathrm{A}_{2}$ but also $\mathrm{A}_{3-5}$ is essential. We therefore conducted a cluster-randomized, controlled trial of the vital sign intervention comparing patientreported rates of tobacco cessation counseling at practices that asked each adult patient about tobacco use when measuring vital signs (intervention) and at practices that continued their usual routine (control). We examined not only the overall counseling rates $\left(\mathrm{A}_{2-5}\right)$ but also the intensity of counseling $\left(A_{2}\right.$ vs $\left.A_{3-5}\right)$.

\section{METHODS}

This study was approved by the institutional review boards of Virginia Commonwealth University and Bon Secours Richmond Health System.

\section{Setting}

Eighteen practices were recruited as research sites under the auspices of the Virginia Ambulatory Care Outcomes Research Network $(\mathrm{ACORN})$, a practice-based research network. ${ }^{22}$ We initially identified 84 practices within a 25 -mile radius of downtown Richmond, Virginia, with at least 1 general internal medicine or family medicine physician on a list of current and former community preceptors of first- or second-year Virginia Commonwealth University medical students. Practices with the full-time equivalent of at least 2 clinicians (family physicians, general internists, nurse-practitioners, or physician's assistants) who specialized in primary care and who provided care to adult patients (wholly or in part) were eligible. We included 1 practice with several primary care clinicians and 1 non-primary care clinician, but excluded the specialist clinician from the study. We excluded residency programs, clinics serving special populations (eg, urgent care centers, indigent/free clinics, student health centers), practices not under the auspices of the overseeing institutional review boards (see above), or practices with an existing systematic tobacco identification and reminder system. The recruitment process entailed a letter of invitation from the principal investigator (S.F.R.) followed by telephone calls to lead physicians and meetings with some office managers and head nurses (A.E.B.). Practices were offered $\$ 500$ for participation and an additional $\$ 1,000$ if assigned to the intervention group.

\section{Data Collection}

Counseling rates were determined by patient selfreport: exit questionnaires administered at the conclusion of their office visit asked adult patients to describe the counseling they had just received. Trained research assistants (RAs) rotating among practices distributed these questionnaires in person. In advance, the project coordinator asked practices to identify potential visit dates during the study period when at least 2 clinicians would be seeing patients but did not reveal on which of these suggested dates RAs would be on site. The number of days that RAs visited each practice was periodically adjusted to balance the number of smokers surveyed at each practice.

RAs attempted to approach each adult patient as he or she exited the clinic area. Patients were eligible if they verbally confirmed that they were aged 18 years or older and had seen a clinician (physician, nurse-practitioner, or physician's assistant) that day. The RA invited patients to complete a self-administered questionnaire, providing limited assistance with uncompleted entries and offering no cessation counseling. Informed consent

\section{Table 1. The 5A Counseling Framework Recommended in the US Department of Health and Human Services Practice Guideline on Smoking Cessation Counseling ${ }^{9}$}

\begin{tabular}{|c|c|c|}
\hline A & Activity & Description \\
\hline$A_{1}$ & Ask & $\begin{array}{l}\text { Identify and document tobacco use status for every patient } \\
\text { at every visit }\end{array}$ \\
\hline $\mathrm{A}_{2}$ & Advise & $\begin{array}{l}\text { In a clear, strong, and personalized manner, urge every } \\
\text { tobacco user to quit }\end{array}$ \\
\hline $\mathrm{A}_{3}$ & Assess & $\begin{array}{l}\text { Determine whether the tobacco user is willing to make a quit } \\
\text { attempt at this time }\end{array}$ \\
\hline $\mathrm{A}_{4}$ & Assist & $\begin{array}{l}\text { For the patient willing to make a quit attempt, use counseling } \\
\text { and pharmacotherapy to help him or her quit }\end{array}$ \\
\hline$A_{5}$ & Arrange & $\begin{array}{l}\text { Schedule follow-up contact, in person or by telephone, prefer- } \\
\text { ably within the first week after the quit date }\end{array}$ \\
\hline
\end{tabular}


was obtained through an RA statement and a written preamble preceding the questionnaire.

The 10 -item questionnaire was designed to obtain patients' perspective on whether $A_{1-5}$ had occurred. Although we created individual questions for $\mathrm{A}_{1}$ (Did a nurse or doctor ask you today if you smoke?) and $\mathrm{A}_{2}$ (If you smoke, did your doctor advise you today to stop smoking?), adapted from previous instruments, ${ }^{23,24}$ we produced a composite question for $\mathrm{A}_{3-5}$ (If you smoke, did your doctor talk with you today about ideas or plans to help you quit smoking?) out of concern that too lengthy a questionnaire would compromise patient participation. The questionnaire included additional questions about patient age and sex, smoking status, counseling about other health behaviors, and the nature of the visit and clinician.

Although not part of the data for this study's primary outcomes, additional data were obtained from patients who indicated that they were current smokers and agreed to take home a more detailed postal questionnaire to complete and mail back. The postal questionnaire asked in greater detail about counseling activities at the visit and about patient and visit factors associated with cessation counseling. Further details about the postal questionnaire and its results will be published separately.

\section{Preintervention Period and Randomization}

Before conducting the intervention, we determined each practice's baseline rate of providing cessation counseling $\left(\mathrm{A}_{2-5}\right)$ by surveying a cross-sectional sample of visiting smokers. This preintervention questionnaire was fielded during a 6-week period (November 2003 to January 2004) to obtain the data needed to control for practice-level variation in our block randomization (see "Data Analysis"). We divided the 18 practices into 5 matched groups with similar preintervention counseling rates by applying a centroid hierarchical clustering method, ${ }^{25}$ modified to require 2 or more practices within each group. We used Microsoft Excel (Microsoft Corp, Redmond, Washington) and a random number generator to randomize practices within the matched groups to the intervention or control condition. Allocation was concealed; once it was determined by the program, investigators informed practices which condition they had been assigned to. The performance of the intervention was evident to clinicians, patients, and investigators, and in this regard the trial was unblinded.

\section{Intervention}

During a 3-week period preceding the launch of the intervention, the project coordinator (A.E.B.) conducted a 1 -hour training session at intervention prac-
Figure 1. Imprint on medical record produced by vital sign stamp.

\begin{tabular}{l}
$\begin{array}{l}\text { Tobacco Use: } \\
\text { (circle one) }\end{array}$ Current Former Never \\
\hline
\end{tabular}

tices on how to implement the vital sign procedure. We invited all nurses and medical assistants responsible for processing arriving patients and escorting them to examination rooms (rooming staff) most office managers and some practice medical directors and physicians also attended the sessions. The trainer gave rooming staff a vital sign rubber stamp (Figure 1) and a description of the study, and instructed them to modify their procedures in 3 ways: (1) stamp the encounter/progress notes where other vital signs were normally recorded, (2) ask every adult patient at every visit whether they used tobacco, and (3) record the answer within the stamped imprint. One intervention practice did not use the rubber stamp but opted to print new progress notes with a modified vital sign format. The intervention did not address the counseling practices of staff or clinicians.

No interventions were undertaken at control practices. In addition, we requested that control practices not adopt a systematic tobacco identification or reminder system during the comparison period.

\section{Comparison Period}

The comparison period lasted 6 months (February through August 2004) and targeted a new crosssectional sample of patients. On the first day of the intervention, we faxed to practices a boldly printed "first day" notice for distribution to rooming staff as a reminder about the protocol. To reinforce continued performance of the intervention, we faxed reports at 6 weeks, 3 months, and 5 months to the office manager at intervention sites, giving only the frequency of patient-reported performance of the intervention. One intervention practice experienced a 2 -month delay in launching the intervention.

\section{Power Analysis}

We accounted for both between-practice variation and variation among patients within practices. Because the standard deviation for between-practice variation in the delivery of $\mathrm{A}_{2-5}$ was not available in the literature, we constructed estimates using quit advice data $\left(\mathrm{A}_{2}\right)$ collected over several years by a large health maintenance organization. We estimated variation for control and intervention practices, respectively, by examining their data before and after the distribution of a smoking cessation guideline. The estimated standard 
deviation for between-practice variation in $\mathrm{A}_{2}$ was $10 \%$ to $12 \%$ and $12 \%$ to $14 \%$, respectively, for intervention practices and control practices. We reasoned that because $A_{2}$ is the most frequently delivered subcomponent of counseling, ${ }_{1}^{11,13,26-28}$ its standard deviation would reasonably approximate variation rates for counseling in general. For control practices, we assumed a counseling rate of $50 \%$ and a between-practice standard deviation of $14 \%$. Given these assumptions, the intracluster correlation coefficient is 0.073 . To estimate points on the power curve, we simulated a sufficient number of 2 -stage samples, using the estimated parameters and varying effect sizes, to achieve a margin of error of $1 \%$ or less. We derived the power curve from the proportion of simulations in which our primary hypothesis would be supported at the .05 level (1-sided test). Our simulation predicted $80 \%$ power to detect a $12 \%$ effect size if we enrolled 18 practices and surveyed 27 preintervention period smokers and 81 comparison period smokers per practice.

\section{Data Analysis}

The main outcome measure $\left(\mathrm{A}_{2-5}\right)$ was counted when patients gave affirmative responses to the question addressing $A_{2}$, the question addressing $\mathrm{A}_{3-5}$, or both. The unit of analysis was the practice, because practices rather than patients or clinicians were randomized. We used an intentionto-treat analysis; at the practice that experienced a 2-month delay in implementing the intervention, data collected during the delay were included as comparison period data. We excluded data from 2 surveyed patients (1 from each study arm) because their 2 clinicians were not represented in both the preintervention and comparison periods.

The number of smokers surveyed at each practice was not uniformly distributed over time, which could have resulted in bias from temporal trends. To account for this possibility, we weighted tification system. the observations within each practice over the comparison period so that the cumulative sampling volume had a constant slope over time. As we also intended to incorporate preintervention counseling rates in the analysis and recognized that the survey volumes attributed to each clinician within practices might differ between the preintervention and comparison periods, we weighted the preintervention data to match the proportions observed in the comparison period.

Using a nested, hierarchical logistic regression model, ${ }^{29}$ we accounted for variation among practices,

\section{Figure 2. Flow diagram of the study.}

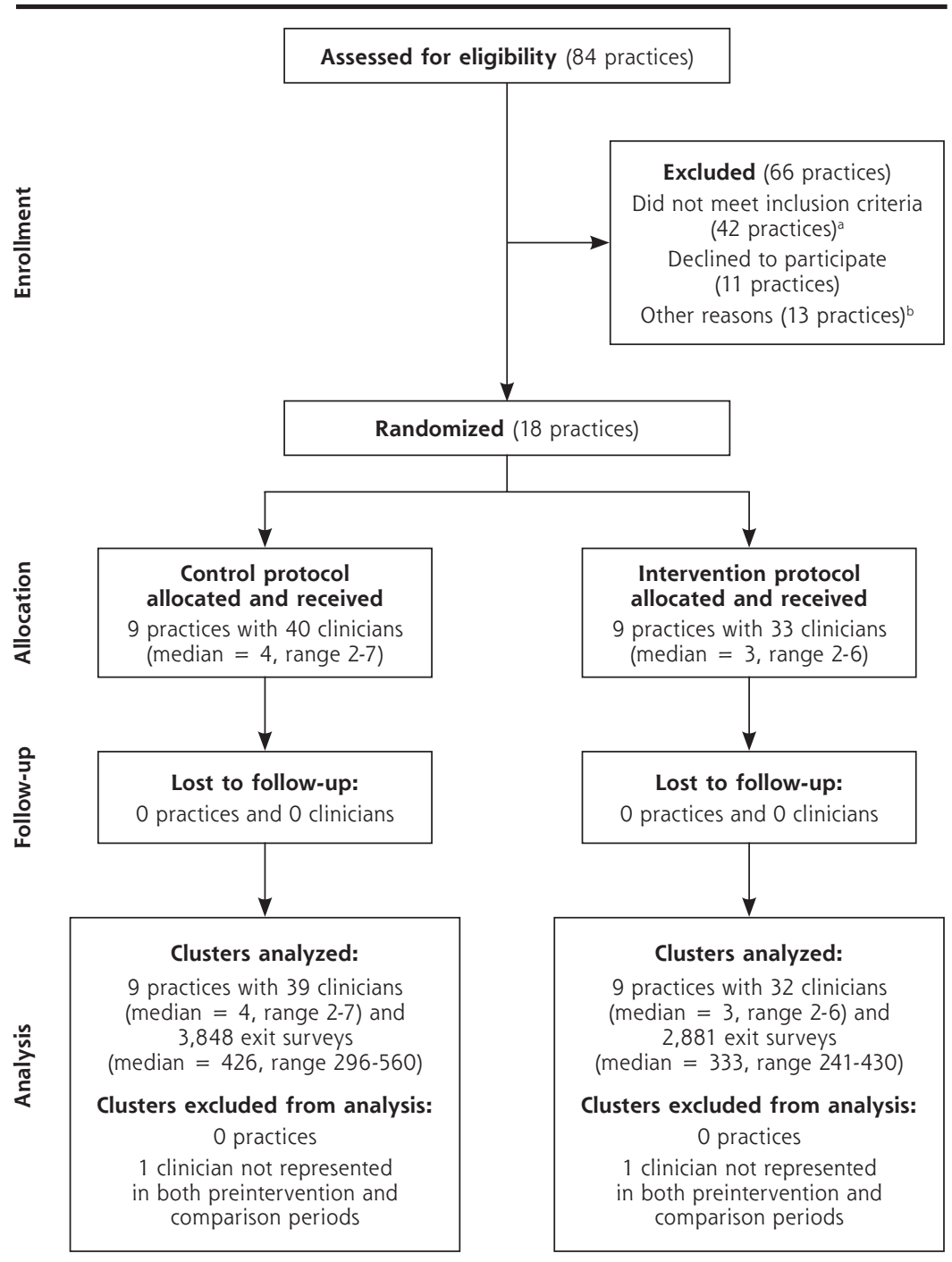

a Twelve were not eligible for oversight by the 2 institutional review boards where this protocol was approved, 12 did not have at least 2 full-time equivalent primary care clinicians who saw any adults, 13 cared for special populations (1 college health clinic, 1 women's health practice, 1 endocrine practice, 2 indigent care clinics, and 8 urgent care centers), 3 were residency training programs, and 2 already used a systematic tobacco iden-

${ }^{b}$ Three practices were approached for recruitment but did not make a participation decision before the enrollment target of 18 was reached, 9 were not approached before reaching the enrollment target, and 1 was the practice location of a study investigator. 
variation among clinicians within practices, and variation among a clinician's patients. The model's independent variables were group assignment, the logit of the weighted preintervention counseling rate, and the matched group. We used the sandwich variance estimator, ${ }^{29}$ which is robust against heteroscedasticity and overdispersion (intracluster correlation). Statistical significance was determined by computing the 1 -sided $P$ value associated with the coefficient of the treatment group independent variable. We used SAS version 9.1 (SAS Institute Inc, Cary, North Carolina, 2002-2003) for power calculations and summary statistics. We used SUDAAN version 8.0 (Research Triangle Institute, Research Triangle Park, NC, 2001) for statistical significance testing.

\section{RESULTS}

The 18 eligible, participating practices included 14 family medicine practices, 3 internal medicine practices, and 1 practice featuring both specialties. Two practices were urban, 2 were rural, and 14 were suburban. Only 1 practice used electronic medical records.

\section{Preintervention Period}

Counseling rates during the preintervention period were determined by administration of the exit questionnaire for 6 weeks to 2,145 patients (384 smokers) at the 18 practices. Counseling rates (the proportion of office visits in which $\mathrm{A}_{2-5}$ was delivered) fell into 5 ranges: $33 \%$ to $38 \%$ (5 practices), $50 \%$ to $53 \%$ (3 practices), $56 \%$ to $60 \%$ (3 practices), $62 \%$ to $65 \%$ (5 practices), and $71 \%$ to $73 \%$ ( 2 practices). These 5 ranges defined the matched groups.

The randomization procedure assigned 9 practices to the vital sign intervention, and there was no attrition of intervention or control practices before or after randomization (Figure 2). The 1 practice with an electronic medical record system was randomized to the control group. Preintervention survey data revealed no statistically significant differences between the intervention and control practices with regard to practice size, clinician or patient characteristics, and frequency of tobacco counseling activities before implementing the intervention, with the exception that intervention patients were an average of 2.4 years younger than control patients $(P=.001)$ (Table 2$)$.

\section{Comparison Period}

During the comparison period, RAs spent 6 to 23 days (median, 14 days) at each practice. On the basis of the reported number of patients making visits (which did not differentiate between pediatric and adult visits), we determined that RAs approached 69\% of patients (and thus a larger proportion of adults). Among potentially eligible patients at the 18 practices, $16.8 \%$ did not
Table 2. Characteristics of Study Groups Surveyed During the Preintervention Period

\begin{tabular}{|c|c|c|c|}
\hline Characteristic & $\begin{array}{l}\text { Control } \\
\text { Group }\end{array}$ & $\begin{array}{l}\text { Intervention } \\
\text { Group }\end{array}$ & $P$ Value ${ }^{a}$ \\
\hline \multicolumn{4}{|l|}{ Practices and clinicians } \\
\hline Number of practices & 9 & 9 & \\
\hline $\begin{array}{l}\text { Number of clinicians per practice, } \\
\text { median (range) }\end{array}$ & $4(2-7)$ & $3(2-6)$ & $.28^{\mathrm{b}}$ \\
\hline Number of clinicians & 40 & 32 & \\
\hline Sex (male), \% & 63 & 76 & .31 \\
\hline Type of clinician, \% & & & .30 \\
\hline Family medicine physicians & 60 & 76 & \\
\hline Internal medicine physicians & 20 & 18 & \\
\hline Nurse-practitioners & 15 & 6 & \\
\hline Physician's assistants & 5 & 0 & \\
\hline Years since licensure, \% & & & .48 \\
\hline $1-5$ & 15 & 12 & \\
\hline $6-10$ & 18 & 18 & \\
\hline $11-20$ & 38 & 21 & \\
\hline $21-30$ & 25 & 42 & \\
\hline$>30$ & 5 & 6 & \\
\hline Race, \% & & & .59 \\
\hline White & 88 & 79 & \\
\hline African American & 0 & 3 & \\
\hline Asian & 3 & 6 & \\
\hline Unknown & 10 & 12 & \\
\hline \multicolumn{4}{|l|}{ Patients } \\
\hline Number of patients & 1,228 & 917 & \\
\hline Age, mean (range), years & $53.0(19-95)$ & $50.6(19-95)$ & $.001^{c}$ \\
\hline Sex (female), \% & 60.3 & 60.0 & .86 \\
\hline Visit for general checkup, \% & 57.5 & 53.3 & .06 \\
\hline Current smoker, \% & 16.7 & 19.6 & .09 \\
\hline \multicolumn{4}{|l|}{ Received cessation counseling ( $\left.5 A^{\prime} s\right), \%$} \\
\hline Asked if smoking $\left(A_{1}\right)$ & 30.9 & 27.2 & .07 \\
\hline Counseled to quit $\left(A_{2-5}\right)^{d}$ & 52.2 & 55.9 & .47 \\
\hline Given simple advice $\left(A_{2}\right)^{d}$ & 50.7 & 53.1 & .68 \\
\hline Had more intensive discussion $\left(A_{3-5}\right)^{d}$ & 27.8 & 33.5 & .27 \\
\hline \multicolumn{4}{|c|}{ 5As $=$ ask $\left(A_{1}\right)$, advise $\left(A_{2}\right)$, assess $\left(A_{3}\right)$, assist $\left(A_{4}\right)$, and arrange $\left(A_{5}\right)$. } \\
\hline $\begin{array}{l}\text { all proportions were tested with the Fisher ex } \\
{ }^{b} \text { Kruskal-Wallis test. } \\
\text { 'Two-sample independent } t \text { test. } \\
\text { d Denominator was restricted to smokers. }\end{array}$ & t test, except whe & e otherwise noted. & \\
\hline
\end{tabular}


participate because they refused, were too ill, had language or vision difficulties, were designated by receptionists as inappropriate participants, or did not answer study-related questions (ie, smoking status, receipt of cessation counseling, and clinician seen). Participation rates did not differ between study groups. No adverse events were reported during the study.

\section{Initial Comparisons}

Across the 18 practices, 6,729 patients (1,149 smokers), including 3,848 patients (588 smokers) from control practices and 2,881 patients (561 smokers) from intervention practices, completed exit questionnaires during the comparison period. Respondent age and sex, the prevalence of current smoking, and the proportion of visits for general checkups did not differ significantly from those reported in the preintervention surveys.

The adjusted proportion of all patients who answered the question addressing $A_{1}$ affirmatively was significantly higher in intervention practices than in control practices $(66.0 \%$ vs $26.3 \%, P<.001)$ (Table 3$)$, providing indirect confirmatory evidence that the vital sign intervention was delivered at intervention practices. The adjusted proportion of smokers answering the $\mathrm{A}_{1}$ question affirmatively was higher in intervention practices as well $(79.5 \%$ vs $49.4 \%, P<.001)$.

\section{Primary Outcome: Smoking Cessation Counseling} of Any Intensity $\left(\mathrm{A}_{2-5}\right)$

Patients at intervention practices were more likely to report they had received some form of smoking cessation counseling $\left(\mathrm{A}_{2-5}\right)$ during their visit, whether it was simple advice, a more extensive discussion, or both. The adjusted proportion of patients reporting such counseling was higher in the intervention group than in the control group $(61.9 \%$ vs $53.4 \%, P=.04)$, with a difference of $8.6 \%$ (Table 3 ).

\section{Secondary Outcomes: Counseling Subcomponents} $\left(\mathrm{A}_{2}\right.$ vs $\left.\mathrm{A}_{3-5}\right)$

The effect of the vital sign intervention on counseling was largely restricted to the delivery of simple advice $\left(\mathrm{A}_{2}\right)$. Analyzed by cluster, the adjusted proportion of patients receiving simple advice was significantly greater in the intervention group than in the control group, by $8.4 \%(59.9 \%$ vs $51.5 \%, P=.04)$; in contrast, the proportion of patients reporting more extensive discussion $\left(\mathrm{A}_{3-5}\right)$ did not differ significantly $(32.5 \%$ vs $29.3 \%, P=.18$ ) (Table 3).

\section{DISCUSSION}

We found that the vital sign intervention improves the frequency of smoking cessation counseling in primary care practices. We observed an $8.6 \%$ proportional increase in counseling that consisted mainly of simple advice to quit $\left(\mathrm{A}_{2}\right)$, with little additional discussion of how to do so $\left(\mathrm{A}_{3-5}\right)$. Six months after the study ended, 4 of the 9 intervention sites reported continuing the vital sign assessment.

A key finding of our study - that most of the observed increase in counseling involved the delivery of simple advice-has important relevance to public health. A Cochrane meta-analysis concluded that 1 of

\section{Table 3. Outcomes of the Intervention, Stratified by Counseling Activity (5A Framework)}

\begin{tabular}{|c|c|c|c|c|c|c|c|}
\hline \multirow[b]{2}{*}{$\begin{array}{l}\text { Counseling } \\
\text { Activity }\end{array}$} & \multirow[b]{2}{*}{$\begin{array}{l}\text { Study } \\
\text { Outcome }\end{array}$} & \multirow[b]{2}{*}{$\begin{array}{l}\text { Question on Exit } \\
\text { Questionnaire }\end{array}$} & \multicolumn{5}{|c|}{ Adjusted Affirmative Response Rate } \\
\hline & & & ICC ${ }^{a}$ & $\begin{array}{l}\text { Control } \\
\text { Group, \% }\end{array}$ & $\begin{array}{l}\text { Intervention } \\
\text { Group, \%c }\end{array}$ & $\begin{array}{l}\text { Difference, \% } \\
\left(95 \% \mathrm{Cl}^{\mathrm{d}}\right)\end{array}$ & $\begin{array}{c}P \\
\text { Value }\end{array}$ \\
\hline Ask $\left(A_{1}\right)$ & Proxy for & "Did a nurse or doctor ask & & & & & \\
\hline All patients & intervention & you today if you smoke?" & 0.040 & 26.3 & 66.0 & $39.7(35.5$ to $\infty)$ & $<.001$ \\
\hline Smokers & & & 0.065 & 49.4 & 79.5 & $30.1(24.0$ to $\infty)$ & $<.001$ \\
\hline Nonsmokers & & & 0.045 & 22.7 & 62.8 & 40.1 (35.3 to $\infty)$ & $<.001$ \\
\hline $\begin{array}{l}\text { Counseling } \\
\left(A_{2-5}\right)\end{array}$ & $\begin{array}{l}\text { Main } \\
\text { outcome }\end{array}$ & (Either or both of below.) & 0.063 & 53.4 & 61.9 & $8.6(0.8$ to $\infty)$ & .04 \\
\hline Advice $\left(A_{2}\right)$ & $\begin{array}{r}\text { Secondary } \\
\text { outcome }\end{array}$ & $\begin{array}{l}\text { "If you smoke, did your doctor } \\
\text { advise you today to stop } \\
\text { smoking?" }\end{array}$ & 0.064 & 51.5 & 59.9 & $8.4(0.7$ to $\infty)$ & .04 \\
\hline $\begin{array}{l}\text { Discussion } \\
\left(A_{3-5}\right)\end{array}$ & $\begin{array}{r}\text { Secondary } \\
\text { outcome }\end{array}$ & $\begin{array}{l}\text { "If you smoke, did your doctor } \\
\text { talk with you today about } \\
\text { ideas or plans to help you } \\
\text { quit smoking?" }\end{array}$ & 0.061 & 29.3 & 32.5 & $3.3(-2.9$ to $\infty)$ & .18 \\
\hline $\begin{array}{l}5 \text { As }=\text { ask }\left(A_{1}\right) \text {, ad } \\
\text { a Estimate of the in } \\
{ }^{b} \text { Nine practices wi } \\
\text { 'Nine practices wi } \\
\text { d The } 95 \% \text { lower c } \\
\text { e Defined as an aff }\end{array}$ & $\begin{array}{l}\text { vise }\left(A_{2}\right) \text {, assess }\left(A_{3}\right. \\
\text { tracluster correlatic } \\
\text { th denominators of } \\
\text { h denominators of } \\
\text { onfidence interval. } \\
\text { rmative response t }\end{array}$ & $\begin{array}{l}\text { assist }\left(A_{4}\right) \text {, and arrange }\left(A_{5}\right) ; I C C=\text { int } \\
=3,848 \text { patients for } A_{1} \text { and } n=588 \\
=2,881 \text { patients for } A_{1} \text { and } n=561 \mathrm{~s}\end{array}$ & $\begin{array}{l}\text { ers for } A_{2} \\
\text { ers for } A_{2-5}\end{array}$ & tion coefficient; & $\mathrm{I}=$ confidence int & rval. & \\
\hline
\end{tabular}




\begin{tabular}{|c|c|c|c|c|c|c|}
\hline \multirow[b]{2}{*}{ Feature } & \multicolumn{6}{|c|}{ Study } \\
\hline & $\begin{array}{c}\text { Robinson et al } \\
\text { (1995) }\end{array}$ & $\begin{array}{c}\text { Fiore et al }{ }^{11} \\
(1995)\end{array}$ & \multicolumn{2}{|c|}{$\begin{array}{c}\text { Ahluwalia et al }{ }^{13} \\
\text { (1999) }\end{array}$} & \multicolumn{2}{|c|}{$\begin{array}{c}\text { Piper et al }{ }^{14} \\
(2003)\end{array}$} \\
\hline Setting & $\begin{array}{l}1 \text { family practice } \\
\text { residency train- } \\
\text { ing site }\end{array}$ & $\begin{array}{l}1 \text { academic } \\
\text { internal medi- } \\
\text { cine clinic }\end{array}$ & \multicolumn{2}{|c|}{1 inner-city residency walk-in clinic } & \multicolumn{2}{|l|}{5 clinics } \\
\hline Design & Before and after & Before and after & \multicolumn{2}{|c|}{$\begin{array}{l}\text { Intervention and control alternating every } \\
2 \text { weeks }\end{array}$} & \multicolumn{2}{|c|}{$\begin{array}{l}\text { Randomization of practices to inter- } \\
\text { vention or control }\end{array}$} \\
\hline $\begin{array}{l}\text { Number of partic- } \\
\text { ipants (smokers) }\end{array}$ & $637(179)$ & $1,864(254)$ & \multicolumn{2}{|l|}{$2,811(883)$} & \multicolumn{2}{|l|}{$9,439(1,611)$} \\
\hline \multicolumn{7}{|l|}{ Ask $\left(A_{1}\right)$} \\
\hline Measure & - & $\begin{array}{l}\text { Patients' report } \\
\text { of physician } \\
\text { asking if they } \\
\text { smoke }\end{array}$ & \multicolumn{2}{|c|}{$\begin{array}{l}\text { Patients' report of physician asking if they } \\
\text { smoked cigarettes }\end{array}$} & \multicolumn{2}{|c|}{$\begin{array}{l}\text { Patients' report of physician asking } \\
\text { if they smoke }\end{array}$} \\
\hline Change $^{b}$ & - & $25.5 \%$ vs $52.6 \%$ & \multicolumn{2}{|l|}{$45.6 \%$ vs $78.4 \%^{c}$} & \multicolumn{2}{|l|}{$24.0 \%$ vs $41.2 \%^{c}$} \\
\hline \multicolumn{7}{|l|}{$\begin{array}{l}\text { Any counseling } \\
\left(A_{2.5}\right)\end{array}$} \\
\hline Measure & $\begin{array}{l}\text { Visits in which } \\
\text { physician dis- } \\
\text { cussed smoking }\end{array}$ & - & \multicolumn{2}{|c|}{ - } & \multicolumn{2}{|l|}{-} \\
\hline Change $^{b}$ & $47 \%$ vs $86 \%$ & - & \multicolumn{2}{|c|}{-} & \multicolumn{2}{|l|}{-} \\
\hline \multicolumn{7}{|l|}{ Advise $\left(A_{2}\right)$} \\
\hline Measure & $\begin{array}{l}\text { Visits in which } \\
\text { physician } \\
\text { advised quitting }\end{array}$ & $\begin{array}{l}\text { Smokers' report } \\
\text { of physician } \\
\text { advice to quit }\end{array}$ & \multicolumn{2}{|c|}{$\begin{array}{l}\text { Smokers' report of physician telling them } \\
\text { to quit }\end{array}$} & \multicolumn{2}{|c|}{$\begin{array}{l}\text { Smokers' report of physician advice } \\
\text { to quit }\end{array}$} \\
\hline Change $^{b}$ & $50 \%$ vs $80 \%$ & $48.8 \%$ vs $69.8 \%{ }^{c}$ & \multicolumn{2}{|l|}{$26.9 \%$ vs $39.9 \%^{c}$} & \multicolumn{2}{|l|}{$60.0 \%$ vs $37.1 \%^{c}$} \\
\hline \multicolumn{7}{|l|}{$\begin{array}{l}\text { Further discussion } \\
\left(A_{3-5}\right)\end{array}$} \\
\hline Measure & $\begin{array}{l}\text { Smokers' report of } \\
\text { physician advice } \\
\text { on how to quit }\end{array}$ & - & & - & - & \\
\hline Change $^{b}$ & $23.8 \%$ vs $42.6 \% c$ & - & & - & - & \\
\hline \multicolumn{7}{|l|}{ Assist $\left(A_{4}\right)$} \\
\hline Measure & - & - & $\begin{array}{l}\text { Smokers' report of } \\
\text { physician helping } \\
\text { to set quit date }\end{array}$ & $\begin{array}{l}\text { Smokers' report of } \\
\text { physician assistance } \\
\text { with how to quit }\end{array}$ & $\begin{array}{l}\text { Smokers' report of } \\
\text { physician helping } \\
\text { to set quit date }\end{array}$ & $\begin{array}{l}\text { Smokers' report } \\
\text { of NRT } \\
\text { prescription }\end{array}$ \\
\hline Change $^{b}$ & - & - & $<1 \%$ vs $<1 \%$ & $2.8 \%$ vs $4.8 \%^{c}$ & $4.4 \%$ vs $1.5 \% c$ & $8.5 \%$ vs $1.9 \%^{c}$ \\
\hline \multicolumn{7}{|l|}{ Arrange $\left(A_{5}\right)$} \\
\hline Measure & - & - & \multicolumn{2}{|c|}{$\begin{array}{l}\text { Smokers' report that physician arranged } \\
\text { follow-up }\end{array}$} & \multicolumn{2}{|l|}{-} \\
\hline Change $^{b}$ & - & - & \multicolumn{2}{|l|}{$6.2 \%$ vs $12.3 \% c$} & \multicolumn{2}{|l|}{ - } \\
\hline
\end{tabular}

NRT $=$ nicotine replacement therapy.

Note: For cells containing a dash (-), there were no equivalent measures or data.

a Exact number of smokers in baseline sample was not reported.

${ }^{b}$ Control vs intervention.

'Change was statistically significant.

${ }^{d}$ Control vs routine vital sign. Change was larger for control vs enhanced vital sign arm of the study.

40 patients who receive simple advice will quit. ${ }^{30} \mathrm{On}$ the basis of this effect size, the smoking rates and magnitude of increased cessation advice observed in our study, and an estimated 5,000 visits per clinician per year, we estimate that a practice of 4 clinicians could expect to gain an additional exsmoker every 6 weeks by adopting the vital sign intervention.

Seven prior studies of the vital sign intervention $^{11-17}$ yielded inconsistent findings with regard to the frequency and intensity of subsequent cessation counseling (Table 4). The only other randomized trial of the vital sign intervention reported no change or a decrease in cessation advice and assistance. ${ }^{14}$ Our study may have greater external validity (generalizability) than prior research because we included more practices (18 vs $1-7)$ and excluded residencies. The internal validity of our study is enhanced by its randomized design and its rigorous approach to data collection and analysis.

Our trial has several limitations. First, as in most prior studies, our outcome measure was counseling rather than smoking cessation, although extensive evi- 


\begin{tabular}{|c|c|c|}
\hline \multicolumn{3}{|c|}{ Study } \\
\hline $\begin{array}{l}\text { Boyle and Solberg }{ }^{15} \\
(2004)\end{array}$ & $\begin{array}{l}\text { Milch et al }{ }^{16} \\
\qquad(2004)\end{array}$ & $\begin{array}{l}\text { Maizlish et } \text { al }^{17} \\
(2006)\end{array}$ \\
\hline 2 clinics & $\begin{array}{l}5 \text { teams in } 1 \text { hospital-based pri- } \\
\text { mary care practice }\end{array}$ & $\begin{array}{l}7 \text { community health } \\
\text { centers }\end{array}$ \\
\hline $\begin{array}{l}\text { Phone survey before and } \\
\text { after institution of vital } \\
\text { sign measure }\end{array}$ & $\begin{array}{l}\text { Nonrandom allocation of } 2 \text { teams } \\
\text { to routine vital signs or enhanced } \\
\text { vital signs; } 3 \text { teams as controls }\end{array}$ & Before and after \\
\hline 4,667 (332) & $3,063(644)$ & $1,571(\approx 267)^{\mathrm{a}}$ \\
\hline $\begin{array}{l}\text { Visits with chart evi- } \\
\text { dence of tobacco use } \\
\text { documentation }\end{array}$ & $\begin{array}{l}\text { Medical record documentation of } \\
\text { smoking status }\end{array}$ & $\begin{array}{l}\text { Medical record docu- } \\
\text { mentation of smoking } \\
\text { status }\end{array}$ \\
\hline $38.0 \%$ vs $78.4 \% c$ & $49 \%$ vs $86 \% c, d$ & $57 \%$ vs $85 \%$ \\
\hline $\begin{array}{l}\text { Visits with chart evi- } \\
\text { dence of tobacco use } \\
\text { documentation }\end{array}$ & $\begin{array}{l}\text { Chart evidence of advising, quit- } \\
\text { ting, setting quit date, referral or } \\
\text { pharmacotherapy }\end{array}$ & - \\
\hline $33.5 \%$ vs $18.8 \%$ & $30 \%$ vs $38 \% \%^{d}$ & - \\
\hline $\begin{array}{l}\text { Smokers' report of } \\
\text { advice to quit }\end{array}$ & - & $\begin{array}{l}\text { Medical record docu- } \\
\text { mentation of advice } \\
\text { to quit }\end{array}$ \\
\hline $66.3 \%$ vs $66.5 \%$ & - & $26 \%$ vs $26 \%$ \\
\hline- & - & - \\
\hline- & - & - \\
\hline- & - & - \\
\hline- & - & - \\
\hline- & - & - \\
\hline- & - & - \\
\hline
\end{tabular}

dence establishes the close linkage between the two. ${ }^{9}$ Second, as in most prior work, we relied on patient report of counseling rather than direct observation (eg, audiotaping), because the latter was too expensive and intrusive. Third, a Hawthorne effect was possible if clinicians knew RAs were at the practice, although such knowledge was less likely given that the visits were unannounced. Fourth, we measured effects for only 6 months and cannot predict sustainability over longer periods. Fifth, office managers at intervention practices received feedback on the rooming staff's performance of the study intervention; although this feedback is unlikely to have affected the clinicians' counseling behavior, it might limit generalizability to practices without such reinforcement. Intervention practices also received $\$ 1,000$ more than did control practices, but this amount is unlikely to explain sustained performance of the intervention for 6 months beyond the study period. Finally, although almost $80 \%$ of smokers reported being asked if they smoke, better performance of this intervention, perhaps through different training than the 1-hour session we used, may have resulted in higher counseling rates.

We conclude that inquiring about smoking status as a routine vital sign in primary care practices should modestly enhance cessation when implemented as a stand-alone intervention. Reminder systems, by themselves, are easy for practices to implement. Our trial confirms data reported by others, ${ }^{13,14}$ however, that this reminder system alone does not translate into more frequent intensive counseling within the practice. To offer this level of assistance, practices and the health plans within which they operate must establish additional systems to overcome barriers to the delivery of smoking cessation counseling and to ensure that patients receive the intensive interventions needed to effect tobacco cessation. They must augment the identification of smokers-the focus of this study-by redesigning management systems, modifying reimbursement algorithms, and forging alliances with community resources to overcome these barriers.
To read or post commentaries in response to this article, see it online at http://www.annfammed.org/cgi/current/full/6/1/60.

Key words: Smoking; tobacco; smoking cessation; vital signs; vital sign intervention; health behavior; counseling; primary care; office visits; practice-based research

Submitted March 6, 2006; submitted, revised, May 15, 2007; accepted June 4, 2007.

Preliminary findings of this work were presented as a poster at the North Primary Care Research Group Meeting, October 12, 2004, 
Orlando, FL; at the AHRQ PBRN Research Conference, July 21, 2005, Washington, DC; and at the North American Primary Care Research Group Meeting, October 16, 2005, Quebec City, Ontario.

Funding support: This study was funded through 2 grants to Dr Rothemich from the Robert Wood Johnson Foundation, including a Generalist Physician Faculty Scholars Program award (036798) and a supplemental grant (043145).

Disclaimer: The Foundation had no role in the design or conduct of the study; the collection, management, analysis, or interpretation of the data; or the preparation, review, or approval of the manuscript. Drs Rothemich and Johnson had full access to all data in the study and take responsibility for the integrity of the data and the accuracy of the data analysis.

Trial registration: ClinicalTrials.gov: NCT00245323.

Acknowledgments: Dr Rothemich, whose work on this topic was made possible by the Robert Wood Johnson Foundation Generalist Physician Faculty Scholars Program, thanks the National Program Office and is especially grateful for the support and guidance he received from C. Tracy Orleans, PhD, and Cynthia D. Mulrow, MD, MSc. The authors also thank the Virginia Ambulatory Care Outcomes Research Network (ACORN); the research assistants who administered the exit questionnaires (Ann Luck, Carolyn Mitchell, and Frances Stewart); and the clinicians, staff, managers, and patients of the participating practices: Ashland Medical Center, Ashland; Aylett Medical Center, Aylett; Cold Harbor Family Medicine, Mechanicsville; Family Physicians of Chester, Chester; Harbour Point Family Practice, Midlothian; Huguenot Primary Care, Midlothian; Internal Medicine Associates of Virginia, Richmond; Ironbridge Family Practice, Chester; King and Queen Family Practice, St Stephens Church; Laburnum Medical Center, Richmond; Memorial Medical Center, Mechanicsville; Midlothian Family Practice, Powhatan; Midlothian Family Practice, Watercove; Midlothian Primary Care, Midlothian; Drs Titus, Hendrix, Turner, Pahle, and Christensen, Richmond; Tuckahoe Family Practice Center, Richmond; Village Green Family Medicine, Midlothian; and Village Medical Associates, Midlothian. The authors are also grateful for editorial assistance and review rendered by Michelle Kienholz.

\section{References}

1. Orleans CT, Woolf SH, Rothemich SF, Marks JS, Isham GJ. The top priority: building a better system for tobacco-cessation counseling. Am J Prev Med. 2006;31(1):103-106.

2. Centers for Disease Control and Prevention. Annual smokingattributable mortality, years of potential life lost, and economic costs-United States, 1995-1999. MMWR Morb Mortal Wkly Rep. 2002:51(14):300-303.

3. 40th Anniversary of the First Surgeon General's Report on Smoking and Health. http://www.cdc.gov/mmwr/preview/mmwrhtml/ mm5303a1.htm. Accessed May 13, 2005.

4. Ockene JK. Smoking intervention: the expanding role of the physician. Am J Public Health. 1987;77(7):782-783.

5. Owen N, Davies MJ. Smokers' preference for assistance with cessation. Prev Med. 1990;19(4):424-431.

6. Russell MA, Wilson C, Taylor C, et al. Effect of general practitioners' advice against smoking. BMJ. 1979;2(6184):231-235.

7. Pine D, Sullivan S, Conn SA, David C. Promoting tobacco cessation in primary care practice. Prim Care. 1999;26(3):591-610.

8. The Agency for Health Care Policy and Research Smoking Cessation Clinical Practice Guideline. JAMA. 1996;275(16):1270-1280.
9. Fiore MC, Bailey WC, Cohen SJ, et al. Treating Tobacco Use and Dependence. Rockville, MD: US Department of Health and Human Services; 2000.

10. Manley MW, Griffin T, Foldes SS, Link CC, Sechrist RA. The role of health plans in tobacco control. Annu Rev Public Health. 2003;24:247-266

11. Fiore MC, Jorenby DE, Schensky AE, Smith SS, Bauer RR, Baker TB. Smoking status as the new vital sign: effect on assessment and intervention in patients who smoke. Mayo Clin Proc. 1995;70(3):209-213.

12. Robinson MD, Laurent SL, Little JM Jr. Including smoking status as a new vital sign: it works! J Fam Pract. 1995;40(6):556-561.

13. Ahluwalia JS, Gibson C, Kenney E, Wallace D, Resnicow K. Smoking status as a vital sign. J Gen Intern Med. 1999;14(7):402-408.

14. Piper ME, Fiore MC, Smith SS, et al. Use of the vital sign stamp as a systematic screening tool to promote smoking cessation. Mayo Clin Proc. 2003;78(6):716-722.

15. Boyle R, Solberg LI. Is making smoking status a vital sign sufficient to increase cessation support actions in clinical practice? Ann Fam Med. 2004;2(1):22-25.

16. Milch CE, Edmunson JM, Beshansky JR, Griffith JL, Selker HP. Smoking cessation in primary care: a clinical effectiveness trial of two simple interventions. Prev Med. 2004;38(3):284-294.

17. Maizlish NA, Ruland J, Rosinski ME, Hendry KA. A systems-based intervention to promote smoking as a vital sign in patients served by community health centers. Am J Med Qual. 2006;21(3):169-177.

18. Hopkins DP, Briss PA, Ricard CJ, et al. The Task Force on Community Preventive Services. Reviews of evidence regarding interventions to reduce tobacco use and exposure to environmental tobacco smoke. Am J Prev Med. 2001;20(2 Suppl):16-66.

19. Lancaster T, Stead L, Silagy C, Sowden A. Effectiveness of interventions to help people stop smoking: findings from the Cochrane Library. BMJ. 2000;321(7257):355-358.

20. Silagy C. Physician advice for smoking cessation. Cochrane Database Syst Rev. 2000;(2):CD000165. Review. Update in Cochrane Database Syst Rev. 2001;(2):CD000165.

21. Lancaster T, Stead LF. Individual behavioural counselling for smoking cessation. Cochrane Database Syst Rev. 2002;(3):CD001292.

22. Nutting PA, Beasley JW, Werner JJ. Practice-based research networks answer primary care questions. JAMA. 1999;281(8):686-688.

23. Current estimates from the National Health Interview Survey, 1993. Vital Health Stat 10. 1994;(190):1-221.

24. Pbert L, Adams A, Quirk M, Hebert JR, Ockene JK, Luippold RS The patient exit interview as an assessment of physician-delivered smoking intervention: a validation study. Health Psychol. 1999;18(2):183-188.

25. Johnson RA, Wichern DW. Applied Multivariate Statistical Analysis. 4th ed. Upper Saddle River, NJ: Prentice Hall; 1998.

26. Cornuz J, Zellweger JP, Mounoud C, Decrey H, Pecoud A, Burnand B. Smoking cessation counseling by residents in an outpatient clinic. Prev Med. 1997;26(3):292-296.

27. Goldstein MG, Niaura R, Willey-Lessne C, et al. Physicians counseling smokers. A population-based survey of patients' perceptions of health care provider-delivered smoking cessation interventions. Arch Intern Med. 1997;157(12):1313-1319.

28. Sesney JW, Kreher NE, Hickner JM, Webb S. Smoking cessation interventions in rural family practices: an UPRNet study. J Fam Pract. 1997:44(6):578-585.

29. Agresti A. Categorical Data Analysis. 2nd ed. Hoboken, NJ: John Wiley \& Sons, Inc; 2002.

30. Lancaster T, Stead L. Physician advice for smoking cessation. Cochrane Database Syst Rev. 2004;(4):CD000165. 